\title{
Introduction
}

Southeast Asian countries have all in various forms experienced the transfer from totalitarian and authoritarian regimes to emerging democracies. Yet, the totalitarian or authoritarian regimes of Southeast Asia do not fit into a simple binary categorization of resolutely authoritarianism due to a combination of factors.' Malaysia and Singapore have long ago experienced competitive authoritarian regimes whilst Cambodia and Vietnam demonstrated hegemonic authoritarianism. In these four countries, the population's political rights remain unfulfilled because people skew the playing field in favour of themselves. The Southeast Asia region also has a closed authoritarian State represented by Brunei, who does not hold elections and controls the basic rights and civil liberties of its population. ${ }^{2}$

The degree of democracy in the region differs from State to State. For example, Indonesia and the Philippines demonstrated electoral democracy that partly succeeded in improving political rights through hybrid democratic-authoritarian regimes through elections. The two countries do not represent a liberal democracy because the rule of law guaranteeing civil liberties and political rights remain in contention. Even though Indonesia succeeded in managing a transitional democracy after 1998, it has been noted that religious freedom and the rights of minorities in the country, especially sexual and religious minorities are still in peril. The rise of radicalism and discriminative laws against minorities has created a deficiency of human rights protection in the country. The Philippines has been known for its long history of electoral democracy. Yet, the country is now trapped in a large scale murders and extra judicial killings due to misguided law enforcement against drugs by Rodrigo Duterte since 2016.

The Indonesian and the Philippine cases assert that the rule of law is undermined, and citizens are unable to keep their government accountable to upholding human rights where governments do not accept their responsibility to conform to human rights standards. The effective protection of human rights depends on the State understanding its obligation to comply with human rights standards. Those in power should refrain from abusing their position and be conscious of the implication that human rights are based on the notion that they cannot treat citizens as they please. National courts and state institutions are

1 Matthew Carlson \& Mark Turner, "Popular perceptions of political regimes in East and Southeast Asia" (2009) 16:2 Democratization 377-398 at 378.

2 Lee Morgenbesser, "The Rise of Sophisticated Authoritarianism in Southeast Asia”, (22 October 2019), online: Medium <https://medium.com/the-machinery-of-government/the-rise-ofsophisticated-authoritarianism-in-southeast-asia-a42742c4bdeb>.

3 Hannah Ellis Petersen, "Rodrigo Duterte's drug war is 'large-scale murdering enterprise' says Amnesty”, the Guardian (8 July 2019), online: <http://www.theguardian.com/world/2019/ jul/08/rodrigo-dutertes-drug-war-is-large-scale-murdering-enterprise-says-amnesty>. 
subsidiary to the promotion of human rights ${ }^{4}$ and institutions with legal competences should be independent of the executive and legislative branches of government.

Institutional "path dependence"assists us analysing why human rights still suffer in the emerging democracies of Southeast Asia. It rationalizes why countries in transition have severe difficulties to switch from a bad trajectory to a good one. ${ }^{5}$ It accentuates how formal rules often fail to constrain political and economic actors and an institutional perspective on development has now become prominent in development thinking. ${ }^{6}$ By employing this explanatory model, we demonstrate how the institutional pillars of the societies in Southeast Asia are assessed and continue to be governed by the same elite who controlled them during totalitarian times.

\section{Transitional justice}

The human rights records of Southeast Asian countries have improved, but generally the region fails to fully realize economic, social and cultural rights as documented by authors of this issue. The root causes and violations of those rights are increasingly included in transitional justice, ${ }^{7}$ which the Office of the United Nations High Commissioner for Human Rights defines as "the full range of processes and mechanisms associated with a society's attempt to come to terms with a legacy of large-scale past abuses, in order to ensure accountability, serve justice and achieve reconciliation". The four tenets of international human rights law have framed international justice and the fight against impunity as: a) the state obligation to investigate and prosecute alleged perpetrators of gross violation of human rights and serious violations of humanitarian law; b) the right to know the truth about past abuses and the fate of disappeared persons; c) the right to reparations for victims of gross violations of human rights and serious violations of international humanitarian law; d) the state obligation to prevent, through different measures, the reoccurrence of such atrocities in the future. ${ }^{9}$

Originally, transitional justice emerged to deal solely with the legacy of large-scale atrocities and to prevent their reoccurrence by focusing on violations of civil and political rights. Truth Commissions have been the common format for such

4 Icelandic Human Rights Centre, "The Role of States”, online: <https://www.humanrights.is/en/ human-rights-education-project/human-rights-concepts-ideas-and-fora/human-rights-actors/therole-of-states>; Morgenbesser, supra note 2.

5 David Cingranelli \& Mikhail Filippov, "Path dependence and human rights improvement" (2020) 19:1 J Hum Rights 19-32.

6 Mariana Prado \& Michael Trebilcock, "Path dependence, development, and the dynamics of institutional reform" (2009) 59:3 Univ Tor Law J 341-380.

7 UN Office of the High Commissioner for Human Rights (OHCHR), Transitional Justice and Economic, Social and Cultural Rights (2014).

8 The rule of law and transitional justice in conflict and post-conflict societies: Report of the Secretary-General, by UN Office of the High Commissioner for Human Rights (OHCHR) (2004).

$9 \quad$ Petersen, supra note 3. 
processes. However, a more holistic understanding of the truth has meant that the commissions also give evidence on violations of economic, social and cultural rights. The latter of the four tenets, the state obligation to prevent future atrocities, is also given more prominence in the process of truth finding. Today, transitional justice increasingly rests on the premise that significant negotiations of power must be manifest for social, economic and political changes to take place. The advancement of human rights requires "that accessible, transparent and effective mechanisms of accountability be established". ${ }^{10}$ Institutional reforms are needed to ensure an independent and impartial judiciary, civilian control of the military and other enforcement personnel and the training of relevant state personnel in human rights and humanitarian law." But, institutional reforms should not only deal with the structural transformation of state institutions, but importantly also with the root causes of conflict or injustices in order to avoid repetition of past violations of human rights and secure justice in accordance with the SDGs.

The Southeast Asian region has a tradition to grant impunity to those responsible for atrocities and severe human rights breaches. Only Timor-Leste has determinedly tried to come to terms with past violations of human rights with the establishment of the Commission for Reception, Truth and Reconciliation at the beginning of the new millennium. The Khmer Rouge war criminal crimes trial in Cambodia provided a historical record of the horror of the Khmer Rouge regime and the top leaders of this barbaric regime were brought to justice. However, many henchmen of the Kmer Rouge are still to be found in central positions in government offices and amongst the political elite. Most prominently, the Prime Minister Hun Sen and other high profile members of the ruling Cambodian People's Party. They were all protected from being legally accountable for their participation in the Marxist-Leninist experiment. In Cambodia, as in other Southeast Asian countries, an emerging democracy has developed on the shoulder of the failure of a totalitarian regime, but it continues to hold the bearings of totalitarianism. Though a multi-party system and free elections formally form the basis of political life in a number of countries in the region, the governments still consist of authoritarian institutions with the military having varying degrees of control on government policies. The old elite are still part of the "new elite" and they remain untouchable. As Mirza Satria Buana testifies in his article on transitional justice, in the case of Indonesia a militaristically authoritarian democracy has replaced a sultanistic oligarchy. The Southeast Asian countries clearly fail to distance themselves from the past by not reforming state institutions comprehensively and disposing of the old elite from them.

10 P Hunt \& S Leader, "Developing and applying the right to the highest attainable standard of health: The role of the UN special rapporteur (2002-2008)" in Glob Health Hum Rights Leg Philos Perspect (2010) 28.

11 Petersen, supra note 3. 
Populism

Populism may unmask itself as a variant of nationalism and national identity. ${ }^{12}$ Populism often shares with nationalism the emphasis on cultural and historical homogeneity and the division between "us", the laudable people, and "them". Whether "them" is the international or national elite, immigrants or supranational institutions they are all accused of letting down the nation-state and its people. ${ }^{13}$ This form of populism is commonly combined with anti-pluralist, culturally conservative and politically illiberal propensities while they strongly adhere to some form of political theology. ${ }^{14}$ That is evident among ASEAN member states where religion is a means to maintain existing social and political order and to fend off advocates of change. The relationship between populism and liberal democracy is fundamentally ambivalent, because populism prioritizes majority rule over other liberal democratic principles, such as institutional checks and balances, deliberation, and minority rights. Strong populist leaders may succeed in destabilizing democratic institutions, challenging the separation of power, and eroding trust in unelected democratic institutions, such as the judicial system..$^{15}$ The employment of a populist rhetoric mediates the economic and political elite's stronghold on power as the public turn their grievances away from the political leaders. Levitsky et $\mathrm{al}^{16}$ warn that especially in unconsolidated democracies populism may erode democratic institutions and operate conducively for competitive authoritarian regimes. In this context Kaltwasser and Mudde" claim that "populism can be both a corrective and a threat to democracy". In unconsolidated democracies populism in government is thought to have a strong negative effects on democracy, while populism in opposition should serve as a guardian of democracy by engaging people in the democratic processes. ${ }^{18}$

International influence on human rights in Southeast Asia

Within the framework of nationalism and its populistic rhetoric is a strong scepticism to international interference in national matters. However, human right issues are an important element in the corporation of the global marketplace ${ }^{19}$ and civil rights, such as human rights for the LGBT+ community, have generally improved in the region.

12 Ulf Hedetoft, "Nationalism and populism", (4 September 2018), online: Saxo Inst <https://saxoinstitute.ku.dk/research/centres/centre-for-the-study-of-nationalism/nationalismand-populism/> University of Copenhagen.

13 Jan-Werner Müller, What Is Populism? (Philadelphia: University of Pennsylvania Press, 2016).

14 Rogers Brubaker, "Between nationalism and civilizationism: the European populist moment in comparative perspective” (2017) 40:8 Ethn Racial Stud 1191-1226.

15 Noam Gidron \& Bart Bonikowski, "Varieties of Populism: Literature Review and Research Agenda” (2013) Weather Cent Int Aff Harv Univ (Working Paper Series) at 21.

16 Steven Levitsky \& James Loxton, "Populism and competitive authoritarianism in the Andes" (2013) 20:1 Democratization 107-136.

17 Cas Mudde \& Cristóbal Rovira Kaltwasser, Populism in Europe and the Americas: Threat or Corrective for Democracy? (Cambridge University Press, 2007).

18 Petersen, supra note 3.

19 Peter Spiro, “The States and International Human Rights” (1997) 66:2 Fordham Law Rev 567. 
International pressure and "bad standing" in the international press and on global social media sites are essential explanations for the advancement of the human rights of sexual minorities. Still, national interests override international cooperation as the region strongly adheres to a policy of no interference in another country's domestic affairs. Regional cooperation, such as ASEAN and the Bali process, have not progressed as intended due to the prioritization of national interest. Therefore, ASEAN has been impotent with regards to the upholding of human rights in member states.

The Southeast Asian countries have also signed up to numerous UN Declarations that aim to secure basic human rights for various population groups. However, treaties hold a strong element of pragmatism and they allow considerable leeway in national translation of their standards. ${ }^{20}$ With no punitive sanctions for neglecting the human rights stipulated in the treaties countries may not feel compelled to respect the treaties. Subsequently, they offer insufficient support for the recognition of human rights in the region.

\section{Particularism vs. Universalism}

The lack of obligation or resentment to sign up to a number of UN Declarations or treaties is arguably a decision by authoritarians to preserve a patrimonial system that protects their privileges and maintains their subordinates' dependence of their benevolence and not of any formalized rights. But, the reluctance may also be explained by the Southeast Asian countries' understanding of universal human rights. Though they respect the notion "universal" they emphasize that it must be applied in accordance with the local and national culture. They argue along the lines that: "a nation's right to its own culture presupposes the safeguard and the opportunity to exercise the nation's right to freely shape its life according to its own tradition, conditioned only by the felt respect of human rights and not by the overbearing and highhanded stances of other states". ${ }^{21}$ The argument demonstrates the tension between universalism and particularism in human rights and the Southeast Asian countries' justification of the local affirmation of difference. The question remains whether national distinctiveness can be unjustly compromised by application of universal standards and methods of rights protection, or whether a particularistic perception of human rights dilutes their protective value or enhances their application to the benefit of local communities and individuals. ${ }^{22}$ Particularism is clearly perceived as less intrusive and foreign than universalism. Particularistic rights represent to a

20 David Kennedy, "International Human Rights Movement: Part of the Problem?” (2002) 15 Harv Hum Rights J 101.

21 Father Robert Araujo, "Sovereignty, Human Rights, and Self-Determination: The Meaning of International Law” (2000) 24:5 Fordham Int Law J 1477.

22 Neil Walker, "Universalism and Particularism in Human Rights: Trade-Off or Productive Tension?” (2012) Edinb Sch Law Res Pap No 201210. 
lesser degree a security risk and a threat to the patrimonial organization of the societies. Hence, the elite has no interest in promoting universal rights.

We know empirically that the change from absolute rules to democracy, especially to multiparty democracy and the securing of effective remedies before the national courts, demands an enormous effort and much time to ensure effective compliance. ${ }^{23}$ Institutional reforms are needed to provide the capacity to restrain the power of past authoritarian rulers. By still maintaining the control of state institutions and through populist policies they succeed in preserving their stronghold on the society and prevent the process of transitional justice that should illuminate the need for social, economic and cultural human rights. The pressure for change and justice must come from the electorates and by granting a voice to subnational authorities on human right matters. Local responsibility lead to greater consciousness and hence a more efficient enforcement of human rights norms.

On behalf of the editorial board, we believe that to better understand human rights realities in the Southeast Asian region there needs to be a commitment to interdisciplinary approaches, ranging from religious, social, political, cultural and legal. Hence, the editor selects five articles which represent these approaches, hoping that readers will increase their knowledge about the past and current human rights realities in the region. All articles published in volume 4 issue 2 have been rigorously appraised by our reviewers who maintain an expertise on these issues. The editorial office should also thankful to the language editor, Saima Raza and copy editor Cindy Claudia Putri who have worked hard to check grammatical errors and reference citations rigorously.

Jember, 19 December 2020

Jesper Kulvmann, Production Editor

Al Khanif, Editor

23 Carlson \& Turner, supra note 1. 